\title{
Effect of Panax ginseng on Carbamazepine Pharmacokinetics in Rabbits
}

\section{Panax ginseng'in Tavşanlarda Karbamazepin Farmakokinetiğine Etkisi}

\author{
(D) Issam Mohammed ABUSHAMMALA ${ }^{1 *}$, (D) Fatma Khaled EL-SHAIKH ALI1, (D) Kamal Fakher ABU SHAMMALEH11, (D) Mohammed Mahmoud TAHA1, \\ (D) Mohammed Yousef MIQDAD2
}

1Al-Azhar University Faculty of Pharmacy, Department of Pharmaceutics and Industrial Pharmacy, Gaza Strip, Palestine

2Al-Azhar University-Gaza, College of Dentistry, Gaza Strip, Palestine

\begin{abstract}
Objectives: Carbamazepine (CBZ) is a well-known drug prescribed to treat epilepsy and the preferred drug for trigeminal neuralgia. This study was conducted to investigate the effect of Panax ginseng extract (PGE) on the disposition of CBZ, a CYP3A4 substrate, in rabbits.

Materials and Methods: An in vivo randomized parallel design was used to examine herb-drug interactions in 12 male rabbits distributed into 2 groups. In the $1^{\text {st }}$ group (control group), 6 rabbits (control group) were administered orally with CBZ suspension ( $30 \mathrm{mg} / \mathrm{kg} / \mathrm{day}$ ) as a single daily dose for 10 days. In the $2^{\text {nd }}$ group (test group), 6 rabbits was treated concomitantly with CBZ and a dose of PGE ( $2.5 \mathrm{mg} / \mathrm{kg} / \mathrm{day}$ ) at the same time as in the $1^{\text {st }}$ group. Blood samples were withdrawn from the marginal ear vein of the rabbits at intervals of 0.0, 0.5, 1.0, 1.5, 2.0, 2.5, 3.0, 4.0, 6.0, 12.0, and $24.0 \mathrm{~h}$.

Results: CBZ had no significantly different pharmacokinetic (PK) parameters, namely, $C_{\text {max }}, t_{\text {max }}, A \cup C_{0-24}, A \cup C_{0-\infty}, t_{1 / 2}$, and $K_{e}$, when it was given alone or concurrently with PGE ( $p \geq 0.05)$.

Conclusion: PGE may unlikely interfere with the PK of CBZ when it is co-administered with CBZ. Therefore, PGE can be used safely without precautions or dose monitoring.
\end{abstract}

Key words: Carbamazepine, Panax ginseng, CYP3A4, drug interaction, pharmacokinetics

öz

Amaç: Karbamazepin (CBZ), epilepsiyi tedavi etmek için reçete edilen, bilinen ve trigeminal nevraljide tercih edilen ilaçtır. Bu çalıșma, Panax ginseng ekstresinin (PGE) tavşanlarda bir CYP3A4 substratı olan CBZ'nin dağılımı üzerindeki etkisini araştırmak için yapıımıştır.

Gereç ve Yöntemler: Bitki-ilaç etkileşimini incelemek için 12 erkek tavşan in vivo rastgele paralel bir tasarım kullanılarak 2 gruba ayrıldı. Birinci gruptaki 6 tavşana (kontrol grubu) 10 gün süreyle günde tek doz CBZ süspansiyonu ( $30 \mathrm{mg} / \mathrm{kg} / \mathrm{gün}$ ) oral yoldan uygulandı. İkinci gruptaki 6 tavşana (test grubu), 1. grupla eş zamanlı olarak CBZ ve bir doz PGE (2,5 mg/kg/gün) birlikte uygulandı. Uygulamayı takiben tavşanların kulak marjinal venlerinden $0,0,0,5,1,0,1,5,2,0,2,5,3,0,4,0,6,0,12,0$ ve 24,0. saatlerde kan örnekleri alındı.

Bulgular: Tek başına veya PGE ile birlikte verildiğinde CBZ'nin, $C_{\text {maks' }}, t_{\text {maks }}, A C_{0-24}, A^{\prime} C_{0-\infty}, t_{1 / 2}$ ve $K_{e}$ gibi farmakokinetik (PK) parametreleri arasında farklılık saptanmadı $(p \geq 0,05)$.

Sonuç: PGE, CBZ ile birlikte uygulandığında, CBZ'nin PK parametreleri etkilenmeyecektir. Bu nedenle PGE, önleme gerek olmadan veya doz takibi yapılmadan güvenle kullanılabilir.

Anahtar kelimeler: Karbamazepin, Panax ginseng, CYP3A4, ilaç etkileşimi, farmakokinetik 


\section{INTRODUCTION}

Carbamazepine (CBZ) is a well-known drug prescribed to treat epilepsy, trigeminal neuralgia, and bipolar depression.,2 The present study is performed to investigate the effect of Panax ginseng extract (PGE) on the disposition of $\mathrm{CBZ}$, the substrate of CYP3A4, in rabbits.

CBZ has several properties involved in clinical interactions with co-administered drugs, herbs, and food. ${ }^{3,4}$ It has a narrow therapeutic index. ${ }^{5}$ It is a constructive inducing enzyme of several cytochrome P450 (CYP450) isoenzymes and subject to autoinduction. 3.6

CBZ-10,11-epoxide (CBZ-E) is the active metabolite of CBZ whose concentration may be modified by concomitant drugs. It is mostly prescribed in codrug features because of its widespread and long-term use, thereby inducing drug interactions. ${ }^{4}$

Drug interactions are often classified as either pharmacokinetic (PK) or pharmacodynamic interactions. ${ }^{7}$ The most tangible interactions that affect the PK of CBZ include those influencing its metabolic rate. ${ }^{5} \mathrm{CBZ}$ is mainly metabolized in the liver through oxidation catalyzed by the CYP450 3A4 enzyme, and less than $5 \%$ of CBZ becomes excreted and remains unchanged in urine. ${ }^{4,8-10} \mathrm{CBZ}-\mathrm{E}$ is the major (up to $80 \%$ ) active metabolite of $\mathrm{CBZ}$, which is further metabolized before excretion through hydration to a trans-dihydrodiol (CBZ-diol). ${ }^{4,11} \mathrm{CBZ}$ is a substrate of CYP450 3A4 and inducer of its enzymatic activity. ${ }^{8.11}$ It can induce its own metabolism ${ }^{4.9}$ through autoinduction, which is a time- and dose-dependent process. ${ }^{12}$ The inhibition or induction of CYP450 enzymes significantly influences drug interactions that can cause unpredictable adverse effects or even therapeutic failures. ${ }^{13}$ Herb-drug interactions are expected, thereby eliciting various clinical effects. Moreover, the increased popularity of herbal medicines can explain the high incidence of herb-drug interactions. ${ }^{14}$ These interactions can occur when the coadministered herbal preparations modulate drug metabolism either to be induced or inhibited by specific CYP enzymes. ${ }^{15,16}$ CBZ-herb interactions are important and have been widely explored, especially when herbs affect the same enzymes involved in CBZ metabolism. ${ }^{17}$

PGE is one of the most popular and widely available herbal supplements. ${ }^{18,19}$ It is mainly used as an adaptogenic, antineoplastic, immunomodulating, cardiovascular, CNS, endocrine, antiinflammatory, antioxidant, antineurological, and hypoglycemic agent. ${ }^{20}$ Several studies have shown that PGE induces the activity of CYP3A4 in the liver and gastrointestinal tract. ${ }^{21,22}$ Moreover, ginsenoside (an active compound in PGE) induces the CYP3A4 activity in vitro by interacting with CBZ, resulting in an increased CBZ metabolism..$^{14}$ The present in vivo research aims to determine the possible herb-drug interactions between PGE and CBZ disposition.

\section{MATERIALS AND METHODS}

\section{Animals and study design}

Twelve healthy male rabbits weighing 3200-3500 g were bought from Assdda Animal Center (Gaza, Palestine). Clinical tests and follow-up care were performed. The rabbits were subjected to fasting for $12 \mathrm{~h}$ and given free access to water before they were treated. The study was carried out at the AUG Faculty of Pharmacy, Gaza, Palestine.

$A n$ in vivo herb-drug interaction study between $\mathrm{CBZ}$ and PGE was conducted in healthy male rabbits. Experiments were carried out in 1 period, and 2 groups of male rabbits were used. The first group of 6 rabbits was given a single oral dose of CBZ (30 mg/kg/day) from an oral suspension of CBZ (Tegreto ${ }^{\circledR}$ ), and the $2^{\text {nd }}$ group of 6 rabbits was administered with the same volume of CBZ suspension combined with a single oral dose of PGE (2.5 mg/kg/day) prepared in laboratories via a special oral gavage for 10 days. CBZ oral suspension and PG capsules were purchased from private pharmacies. The dose was given to each rabbit via oral gavage by placing the drug in a corner of the rabbit's mouth, and the suspension was pushed down at a slow rate to prevent choking. Physical tests were subsequently carried out to assess clinical safety.

\section{Blood sample collection}

The hair on the rabbits' ear was removed as the marginal ear vein was located. Local anesthetic (4\% lidocaine) was used to prevent the jerking of the rabbits. An IV cannula was installed in the marginal ear vein of each rabbit. Then, $1 \mathrm{~mL}$ of blood sample was collected in vacutainer tubes at the following time points: $0.0,0.5,1.0,1.5,2.0,2.5,3.0,4.0,6.0,12.0$, and $24.0 \mathrm{~h}$ after the last dose was received. Blood samples were centrifuged at $3,000 \mathrm{rpm}$ for $5 \mathrm{~min}$, and serum was separated, collected into clean tubes, and kept at $2^{\circ} \mathrm{C}-8^{\circ} \mathrm{C}$ for analysis within $24 \mathrm{~h}$.

\section{Analysis of $C B Z$ serum samples}

CBZ blood concentrations were assayed via a chemiluminescent immunoassay by using an ARCHITECT analyzer (1000 Abbott Laboratories, Abbott Park, IL, USA).

\section{Pharmacokinetic analysis}

The following PK parameters of both groups were determined: $C_{\text {max }}, t_{\max }, A U C_{0-1,}, A U C_{0-\infty}, t_{1 / 2}$, and $K_{e} . C_{\text {max }}$ and $t_{\max }$ were directly identified from the plasma concentration versus time curves. $\mathrm{AUC}_{0-24}$ was calculated in accordance with the linear trapezoidal rule by using the following equation: $A U C_{0-\infty}=A U C_{0-24}+C t / K_{e^{\prime}}$ where $\mathrm{Ct}$ is the last measured serum concentration at time $\mathrm{t}$, and $\mathrm{K}_{e}$ is the elimination rate constant. $\mathrm{K}_{e}$ was determined via the least squares regression of plasma concentration-time data points in the terminal region by considering the semilogarithmic dependence that corresponds to first-order kinetics. $t_{1 / 2}$ was calculated as $0.693 / \mathrm{K}_{\mathrm{e}}$. PK analysis was conducted via an independent model method (non-compartmental approach) in WinNonlin version 6.3 (Pharsight Corporation, Cary, NC) and GraphPad Prism version 4.00 (San Diego, CA, USA).

\section{Statistical analysis}

Statistical methods, including descriptive analysis and MannWhitney $U$ test, were applied to compare the PK parameters of CBZ alone or with PGE. SPSS version 16.0 was applied to analyze data. Data were considered significantly different when $\mathrm{p} \leq 0.05$. 


\section{RESULTS}

The plasma concentration versus time profiles and PK parameters of CBZ (Figure 1) were compared after it was administered alone (control group) and combined with PGE (test group). The significant results of their comparison are given in Table 1.

\section{DISCUSSION}

CYP3A4 is one of the major CYP enzymes catalyzing $50 \%$ of drug metabolism ${ }^{23,24}$ and participating in the metabolism of CBZ, so any drug affecting CYP3A4 has the potential to cause a drug interaction with CBZ. ${ }^{4}$ Several popular herbs have been considered strong candidates for interactions with medicinal drugs. Therefore, herb-CYP interactions may have significant clinical and toxicological consequences. ${ }^{15}$

The plasma profiles of CBZ are illustrated in Figure 1. $\mathrm{AUC}_{0}$ 24 and $\mathrm{AUC}_{0-\infty}$ apparently decreased after the concomitant administration of CBZ with PGE, but this change was not

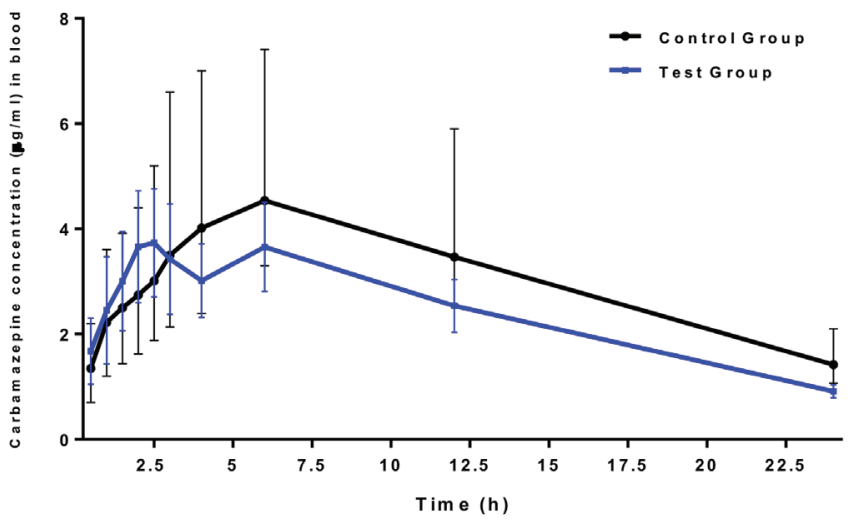

Figure 1. Plot of the mean serum concentration-time profile of CBZ alone (control group) and co-treatment with PGE $(2.5 \mathrm{mg} / \mathrm{kg} /$ day; test group) CBZ: Carbamazepine, PGE: Panax ginseng extract statistically significant $(p \geq 0.05)$. The other $P K$ parameters of both groups were also not altered significantly after PGE administration. The mean $\mathrm{C}_{\max }$ of the control group slightly decreased compared with that of the test group $(p=0.53)$. Despite the decreased half-life $\left(t_{1 / 2}\right)$ from $26.51 \pm 25.79 h$ to $16.99 \pm 8.58 \mathrm{~h}$ in the control and test groups, respectively, their differences were not statistically significant ( $p=0.24)$.

PGE is an herbal medicine used worldwide for a variety of purposes. ${ }^{25}$ With complicated PK and pharmacodynamics, PGE may pose a significant risk for patients once it is taken synchronously with other medications through PGE-drug interactions. $^{26}$

Possible drug interactions have been reported between PGE and warfarin, phenelzine, and alcohol. ${ }^{19,25}$ CBZ may reduce the blood concentrations of warfarin and induces mania if it is used synchronously with phenelzine. ${ }^{27}$

Similarly, Abushammala ${ }^{17}$ found that valerian does not alter the PK parameters of CBZ in rabbits and concluded that CBZ can be used safely with valerian preparations. Moreover, clinical trials have shown that American ginseng does not significantly affect the PK of indinavir and zidovudine. No significant differences in the AUC of the plasma concentration versus time relationship are observed after the co-administration of American ginseng compared with that after either zidovudine or indinavir is administered alone. ${ }^{28,29}$ Despite the stimulating effect of PGE on the CYP3A4 activity, the PK parameters of CBZ do not significantly affect healthy rabbits after the combined administration.

\section{CONCLUSION}

Under the experimental conditions, CBZ and PGE can be used safely without precautions or dose monitoring. However, more studies on humans should be designed to confirm our obtained results. Further research should also be performed by setting

Table 1. Pharmacokinetic parameters of CBZ alone and with PGE in healthy male rabbits (6 rabbits for each group)

\begin{tabular}{|c|c|c|c|c|c|}
\hline PK parameter & Group & $\mathrm{N}$ & Mean \pm SD & Median \pm IQR & $p$ value \\
\hline \multirow{2}{*}{$\mathrm{C}_{\max }$} & CBZ alone & 6 & $4.66 \pm 1.44$ & $4.31 \pm 1.69$ & \multirow{2}{*}{0.818} \\
\hline & $\mathrm{CBZ}+\mathrm{PGE}$ & 6 & $4.16 \pm 0.95$ & $4.14 \pm 1.83$ & \\
\hline \multirow{2}{*}{$t_{\max }$} & CBZ alone & 6 & $5.33 \pm 1.03$ & $6.00 \pm 2.00$ & \multirow{2}{*}{0.394} \\
\hline & $\mathrm{CBZ}+\mathrm{PGE}$ & 6 & $4.08 \pm 2.11$ & $4.25 \pm 4.00$ & \\
\hline \multirow{2}{*}{$t_{1 / 2}$} & CBZ alone & 6 & $30.35 \pm 18.81$ & $26.51 \pm 25.79$ & \multirow{2}{*}{0.240} \\
\hline & $\mathrm{CBZ}+\mathrm{PGE}$ & 6 & $17.51 \pm 4.45$ & $16.99 \pm 8.59$ & \\
\hline \multirow{2}{*}{$\mathrm{K}_{\mathrm{e}}$} & CBZ alone & 6 & $0.03 \pm 0.02$ & $0.03 \pm 0.02$ & \multirow{2}{*}{0.240} \\
\hline & $\mathrm{CBZ}+\mathrm{PGE}$ & 6 & $0.04 \pm 0.01$ & $0.04 \pm 0.01$ & \\
\hline \multirow{2}{*}{$A \cup C_{0-24}$} & CBZ alone & 6 & $71.22 \pm 25.04$ & $63.63 \pm 26.85$ & \multirow{2}{*}{0.394} \\
\hline & $\mathrm{CBZ}+\mathrm{PGE}$ & 6 & $57.41 \pm 10.58$ & $61.06 \pm 19.56$ & \\
\hline \multirow{2}{*}{$A \cup C_{0-\infty}$} & CBZ alone & 6 & $120.56 \pm 64.65$ & $92.76 \pm 113.89$ & \multirow{2}{*}{0.132} \\
\hline & $\mathrm{CBZ}+\mathrm{PGE}$ & 6 & $80.29 \pm 12.25$ & $82.48 \pm 19.13$ & \\
\hline
\end{tabular}

CBZ: Carbamazepine, PGE: Panax ginseng extract, PK: Pharmacokinetic, SD: Standard deviation, IQR: Interquartile range 
higher PGE doses, a longer treatment duration, and a larger sample size.

\section{ACKNOWLEDGMENT}

The authors would like to thank the staff of the Faculty of Pharmacy at AUG for providing support and help and Mr. Mohamed Abu Affash, the director of MRS-Gaza, for facilitating the analysis at the laboratory of their institution.

Conflicts of interest: No conflict of interest was declared by the authors. The authors alone are responsible for the content and writing of the paper.

\section{REFERENCES}

1. Bertilsson L, Tomson T. Clinical pharmacokinetics and pharmacological effects of carbamazepine and carbamazepine-10,11-epoxide. An update. Clin Pharmacokinet. 1986;11:177-198.

2. Whalen K, Finkel R, Panavelil TA. Lippincott illustrated reviews: pharmacology, $6^{\text {th }}$ ed. Wolters Kluwer; 2015:158-163.

3. Patsalos PN, Fröscher W, Pisani F, van Rijn CM. The importance of drug interactions in epilepsy therapy. Epilepsia. 2002;43:365-385.

4. Spina E, Pisani F, Perucca E. Clinically significant pharmacokinetic drug interactions with carbamazepine. An update. Clin Pharmacokinet. 1996;31:198-214.

5. Pynnönen S, Mäntylä R, lisalo E. Bioavailability of four different pharmaceutical preparations of carbamazepine. Acta Pharmacol Toxicol (Copenh). 1978;43:306-310.

6. Guengerich FP. Reactions and significance of cytochrome P-450 enzymes. J Biol Chem. 1991;266:10019-10022.

7. Bailie GR, Johnson CA, Mason NA, Peter W. Medfacts pocket guide of drug Interactions, $2^{\text {nd }}$ ed. Verona, USA; Nephrology Pharmacy Associates Inc; 2004;3-7.

8. Ayano G. Bipolar disorders and carbamazepine: Pharmacokinetics, pharmacodynamics, therapeutic effects and indications of carbamazepine: review of articles. J Neuropsychopharmacol Ment Health. 2016;1:112.

9. Panday DR, Panday KR, Basnet M, Kafle S, Shah B, Rauniar GP. Therapeutic drug monitoring of carbamazepine. Int J Neurorehabil. 2017;4:245.

10. Tolou-Ghamari Z, Zara M, Habibabad JM, Najafi MR. A quick review of carbamazepine pharmacokinetics in epilepsy from 1953 to 2012. J Res Med Sci. 2013;18(Suppl 1):S81-85.

11. Larkin JG, McLellan A, Munday A, Sutherland M, Butler E, Brodie MJ. A double-blind comparison of conventional and controlled-release carbamazepine in healthy subjects. Br J Clin Pharmacol. 1989;27:313322.

12. Rapeport WG. Factors influencing therelationship between carbamazepine plasma concentration and its clinical effects in pationts with epilepsy. Clin Neuropharmacol. 1985;8:141-149.
13. Lynch T, Price A. The effect of cytochrome P450 metabolism on drug response, interactions and adverse effects. Am Fam Physician. 2007;76:391-396.

14. Fong SYK, Gao Q, Zuo Z. Interaction of carbamazepine with herbs, dietary supplements, and food: A systematic review. Evid Based Complement Alternat Med. 2013;2013:898261.

15. Delgoda R, Westlake AC. Herbal interactions involving cytochrome P450 enzymes: a mini review. Toxicol Rev. 2004:23:239-249.

16. Hellum BH, Hu Z, Nilsen OG. The induction of CYP1A2, CYP2D6 and CYP3A4 by six trade herbal products in cultured primary human hepatocytes. Basic Clin Pharmacol Toxicol. 2007;100:23-30.

17. Abushammala I. The effect of valerian on the pharmacokinetics of carbamazepine in healthy rabbits. International Journal of Pharmaceutical Sciences and Research. 2014;9:3641-3645.

18. Seervi CH, Kirtawade R, Dhabale P, Salve P. Ginseng- multipurpose herb. J Biomed Sci Res. 2010;2:6-17.

19. Radad KH, Gille G, Rausch WD. Use of ginseng in medicine: Perspectives on CNS disorders. Iranian J Pharmacol Ther. 2004;3:30-40.

20. Kim J, Cho SY, Kim SH, Kim S, Park CW, Cho D, Seo DB, Shin SS. Ginseng berry and its biological effects as a natural phytochemical. Nat Prod Chem Res. 2016;4:209.

21. Hao M, Ba Q, Yin J, Li J, Zhang R, Wang H. Deglycosylated ginsenosides are more potent inducers of CYP1A1, CYP1A2 and CYP3A4 expression in HepG2 cells than glycosylated ginsenosides. Drug Metab Pharmacokinet. 2011;26:201-205.

22. Malati CY, Robertson SM, Hunt JD, Chairez C, Alfaro RM, Kovacs JA, Penzak SR. Influence of Panax ginseng on cytochrome P450 (CYP)3A and P-glycoprotein (P-gp) activity in healthy participants. J Clin Pharmacol. 2012;52:932-939.

23. Anzenbacher P, Anzenbacherova E. Cytochromes P450: Review on their basic principles. Proc Indian Natn Sci Acad. 2003;6:883-991.

24. Fasinu PS, Bouic PJ, Rosenkranz B. An Overview of the evidence and mechanisms of herb-drug interactions. Front Pharmacol. 2012;3:69.

25. Lakshmi T, Anitha R, Geetha RV. Panax ginseng a universal panacea in the herbal medicine with diverse pharmacological spectrum -a review. Asian Journal of Pharmaceutical and Clinical Research. 2011;4:14-18.

26. Qi LW, Wang CZ, Du GJ, Zhang ZY, Calway T, Yuan CS. Metabolism of ginseng and its interactions with drugs. Curr Drug Metab. 2011;12:818822.

27. Izzo AA, Ernst E. Interactions between herbal medicines and prescribed drugs: a systematic review. Drugs. 2001;61:2163-2175.

28. Andrade AS, Hendrix C, Parsons TL, Caballero B, Yuan CS, Flexner CW, Dobs AS, Brown TT. Pharmacokinetic and metabolic effects of American ginseng (Panax quinquefolius) in healthy volunteers receiving the HIV protease inhibitor indinavir. BMC Complement Altern Med. 2008;8:50

29. Lee LS, Wise SD, Chan C, Parsons TL, Flexner C, Lietman PS. Possible differential induction of phase 2 enzyme and antioxidant pathways by American ginseng, Panax uinquefolius. J Clin Pharmacol. 2008;48:599609. 